In vitro cultivation of Maritrema novaezealandensis (Microphallidae) the effect of culture medium on excystation, survival and egg production

Fredensborg, Brian Lund; Poulin, R

Published in:

Parasitology Research

DOI:

$10.1007 / \mathrm{s} 00436-004-1293-3$

Publication date:

2005

Citation for published version (APA):

Fredensborg, B. L., \& Poulin, R. (2005). In vitro cultivation of Maritrema novaezealandensis (Microphallidae): the effect of culture medium on excystation, survival and egg production. Parasitology Research, 95(5), 310-3. https://doi.org/10.1007/s00436-004-1293-3 


\section{In vitro cultivation of Maritrema novaezealandensis (Microphallidae): the effect of culture medium on excystation, survival and egg production}

Received: 8 November 2004/ Accepted: 23 November 2004/Published online: 29 January 2005

(C) Springer-Verlag 2005

\begin{abstract}
In this study, the effect of the composition of culture medium on excystation, growth, survival and egg production was investigated for the recently discovered microphallid trematode Maritrema novaezealandensis. Metacercariae from the two second intermediate crab hosts, Macrophthalmus hirtipes and Halicarcinus whitei, were incubated in either: (1) $0.85 \%$ saline solution, (2) the commercial cell culture medium, NCTC-109, (3) NCTC-109 supplemented with $20 \%$, or (4) NCTC-109 supplemented with $40 \%$ chicken serum. Furthermore, excysted metacercariae were cultured for 5 days in each of the three media: NCTC-109 and NCTC-109 supplemented with $20 \%$ or $40 \%$ chicken serum. Excystment was rapid for all media used in the experiment. However, metacercariae in $0.85 \%$ saline solution had a significantly lower excystment rate over the first $4 \mathrm{~h}$ of incubation compared to the other media. Egg production was highest in specimens cultured in media with a supplement of chicken serum and reached a maximum after 2 days of cultivation. Growth, however, did not occur after the first day of cultivation in any of the three media.
\end{abstract}

\section{Introduction}

Excystation of trematode metacercariae may be triggered by various biotic and abiotic factors, often in a species-specific manner (Lackie 1975). In Microphallidae, some species show little specificity, and activation and excystment are mainly stimulated by an increase in temperature towards the body temperature of the definitive vertebrate host (Lackie 1975; Irwin 1997;

B. L. Fredensborg $\cdot$ R. Poulin $(\bowtie)$

Department of Zoology, University of Otago, PO Box 56, Dunedin, New Zealand

E-mail: robert.poulin@stonebow.otago.ac.nz

Fax: + 64-3-4797584
Khan et al. 2003). In comparison to more primitive trematodes, microphallids show advanced development of genitalia (often referred to as progenesis) in the metacercarial stage and production of eggs typically starts shortly ( 1 or 2 days) after infection of the definitive host (Galaktionov and Dobrovolskij 2003). This pattern can be repeated successfully when microphallids are cultivated in an appropriate medium (e.g. Fujino et al. 1977; Davies and Smyth 1979). The ideal composition of the medium for development and egg production, however, varies according to the host species and the preferred site of infection within the gastrointestinal tract of the definitive host (Irwin 1997). Hence, in bird trematodes, media enriched with chicken serum have been used successfully to stimulate the production of normally developed eggs (Berntzen and Macy 1969; Basch et al. 1973).

Recently, a new microphallid trematode, Maritrema novaezealandensis, has been described from the intertidal mudflats of New Zealand (Martorelli et al. 2004). The first intermediate host of $M$. novaezealandensis is the New Zealand mudsnail, Zeacumantus subcarinatus. Encysted metacercariae are found mainly in the hepatopancreas of four species of crustaceans, and adult worms live in the gastrointestinal tract of shorebirds (Fredensborg et al. 2004a; Martorelli et al. 2004). Due to its commonness and negative impact on intermediate host ecology, $M$. novaezealandensis is an important species in the soft bottom intertidal community (see Fredensborg et al. 2004b; Thompson et al. 2004).

The main objective of this study was to investigate the effect of the composition of culture medium on in vitro excystation, growth, survival and egg production of $M$. novaezealandensis. Besides providing the first data on in vitro cultivation of this recently discovered trematode, this study adds information to the general knowledge of in vitro excystation and cultivation of microphallids. This information is important not only for the resolution of life cycles in vitro, but also, increasingly, for evolutionary studies of parasite strategies (Wang and Thomas 2002; Brown et al. 2003). 


\section{Materials and methods}

Thirteen Macrophthalmus hirtipes and one Halicarcinus whitei were sampled by hand during low tide in Lower Portobello bay, Otago Harbour, South Island, New Zealand $\left(45^{\circ} 52^{\prime} \mathrm{S}, 170^{\circ} 42^{\prime} \mathrm{E}\right)$. The crabs were transferred to the laboratory and placed in plastic containers halffilled with aerated seawater until dissection. In the laboratory, the crabs were dissected and examined using a microscope at $10 \times$ magnification. Metacercariae of $M$. novaezealandensis were dissected free of the hepatopancreas and other soft tissue in the body cavity of the crabs.

\section{Excystation experiment}

Metacercariae recovered from three $M$. hirtipes and one $H$. white $i$ were individually transferred to a multi-welled plastic plate (using a $100 \mu \mathrm{l}$ Eppendorf pipette), with one cyst per well, in $1 \mathrm{ml}$ of culture medium. To avoid any effect of the intensity of infection in the crabs on the excystation rate, mature metacercariae from each crab were randomly and equally divided into four groups, one for each treatment. In total, 48 metacercariae were placed in each of the following four culture media: (1) a physiological saline solution $(0.85 \% \mathrm{NaCl}),(2) \mathrm{NCTC}$ 109 (GIBCO), (3) NCTC 109 supplemented with 20\% chicken serum, and (4) NCTC-109 supplemented with $40 \%$ chicken serum. NCTC-109 is a commerciallyavailable medium commonly used for cell culture. The chicken serum used in the two latter treatments was initially inactivated at $56^{\circ} \mathrm{C}$ for $30 \mathrm{~min}$ as recommended by Yasuraoka et al. (1974). Penicillin (200 units $/ \mathrm{ml}$ ) and streptomycin $(100 \mu \mathrm{g} / \mathrm{ml})$ were added to all three media before the culture plates were covered and incubated at $40^{\circ} \mathrm{C}$. Each well was inspected at 1, 2, 3, 4, 5 and $24 \mathrm{~h}$ after incubation to assess the excystation success and rate for the four media used in the experiment.

Egg production and survival

On two occasions, metacercariae from $M$. hirtipes were incubated in NCTC- 109 at $40^{\circ} \mathrm{C}$. After $1 \mathrm{~h}$, excysted metacercariae were transferred in groups of five individuals to $0.5 \mathrm{ml}$ Eppendorf microtubes containing $0.5 \mathrm{ml}$ of medium. Media used were the same as for the excystation experiment except for the $0.85 \%$ saline. On each occasion, 15 replicates of five individuals were prepared for each medium. At 24, 48, 72, 96, and $120 \mathrm{~h}$ after incubation three replicates of five individuals were examined from each medium. For each replicate, $\mathrm{pH}$ was measured using a $\mathrm{pH}$-indicator strip and individuals were checked for survival, which was determined by movement. Live trematodes were fixed in hot $5 \%$ formaldehyde and transferred to microscope slides for measurements of body length and width and to count the number of eggs present in the uterus. A standard amount of liquid was added to each specimen and a coverslip was added. This increased the size of the specimen slightly (B. Fredensborg, personal communication) but facilitated measurements and egg counts by flattening the worm. Only apparently normal eggs containing operculum, ovum and vitelline cells were counted. In addition, width and length were measured on a subsample of eggs ( $n=3$ per worm) from all three treatments for comparison with previously derived eggs from the natural definitive host. In addition, egg volume was estimated using the formula for an ellipsoid $\left[\left(V=\pi \times L \times W^{2}\right) / 6\right.$, where $L$ is length and $W$ is width). Measurements of in vitro adults and eggs were performed using a microscope at $100 \times$ and $400 \times$ magnification, respectively.

Data were analysed using parametric tests whenever possible. Number of eggs was transformed $(\log x+1)$ prior to analysis to the meet assumptions for normality. All tests were two-tailed and used the 5\% level of significance.

\section{Results and discussion}

Excystation experiment

Three $M$. hirtipes (carapace width: $6.8-13.1 \mathrm{~mm}$ ), and one $H$. whitei (carapace width: $7.2 \mathrm{~mm}$ ) were dissected for retrieval of $M$. novaezealandensis metacercariae. Numerous $M$. novaezealandensis metacercariae were found in the body cavity of all three $M$. hirtipes specimens (range: 29-112) and in the H. whitei (335). Excystation of metacercariae was rapid for all four treatments (Fig. 1), with most of the metacercariae

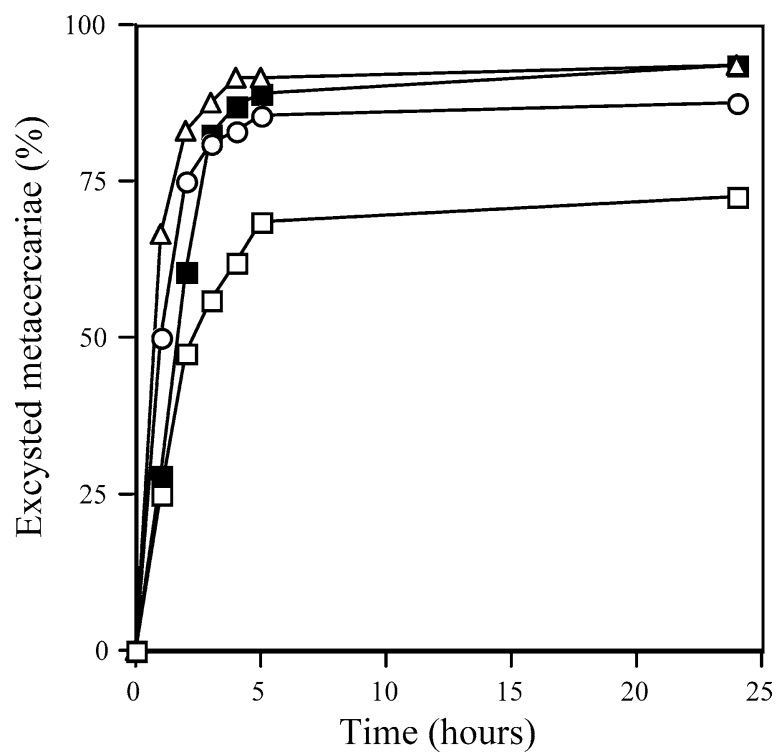

Fig. 1 Excystation of Maritrema novaezealandensis metacercariae as a function of time in four different media incubated at $40^{\circ} \mathrm{C}$. The four media used were: $0.85 \% \mathrm{NaCl}$ solution (empty squares), NCTC-109 only (empty circles), NCTC-109+20\% chicken serum (empty triangles), and NCTC- $109+40 \%$ chicken serum (filled squares $),(n=48$ for each medium $)$ 


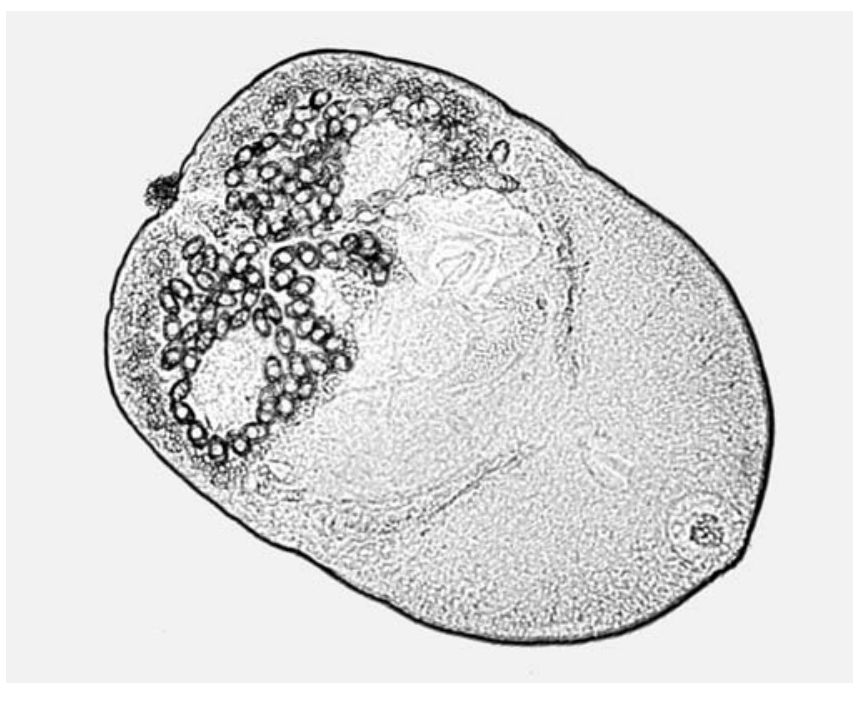

Fig. 2 In vitro adult Maritrema novaezealandensis cultured for $48 \mathrm{~h}$ in NCTC-109 supplemented with $20 \%$ chicken serum at $40^{\circ} \mathrm{C}$. The specimen was fixed in hot $5 \%$ formalin and slightly flattened $(\times 82.5)$. Note many eggs in the uterus

having excysted within a few hours of incubation at $40^{\circ} \mathrm{C}$. These results suggest that temperature is the main trigger for excystment in this species, which is consistent with studies on other microphallids (Fujino et al. 1977; Khan et al. 2003). However, metacercariae in NCTC109 with or without chicken serum had a higher excystation success in the first $4 \mathrm{~h}$ after incubation compared to metacercariae in $0.85 \% \mathrm{NaCl}$ (Yates corrected $\chi^{2}$-test, $P<0.05$ for all comparisons of NCTC-109 treatments with $0.85 \% \mathrm{NaCl}$ ), suggesting that chemical factors also contribute to the initiation of excystment in $M$. novaezealandensis.

\section{Cultivation experiment}

Results from the two separate cultivation experiments were similar and data on cultivation was subsequently pooled. Metacercariae from ten $M$. hirtipes (carapace width: $8.1-21.0 \mathrm{~mm}$ )(range: 7-278 per crab), were used in this experiment. Practically all trematodes survived the first 4 days of cultivation irrespective of culture medium (survival $=99.2 \%$ ). From day 4 to day 5, survival dropped to $79.8 \%$, but did not differ between media ( $\chi^{2}$ test: $\left.P>0.05\right)$. In all culture media, $\mathrm{pH}$ was 8.0 and did not change over the course of the experiment.

For all three culture media, 'normal' eggs, containing an operculum, ovum and vitelline cells were observed in the uterus of the in vitro adult worms (Fig. 2). These had identical dimensions and appearance to eggs from adult $M$. novaezealandensis derived from the natural bird definitive host (Martorelli et al. 2004). The number of eggs in the uterus of in vitro adult worms varied over the course of the experiment for all three media used (Kruskal-Wallis-test, all, $P<0.0001$ ). However, the variation within treatments was also considerable (Table 1). The maximum number of eggs was observed after $48 \mathrm{~h}$ of cultivation, after which egg production decreased for the remaining time of the experiment. At 24 and $48 \mathrm{~h}$ of cultivation, egg production differed significantly between groups (one-way ANOVA: $F_{2,87}=9.12, P<0.0001 ; F_{2,90}=6.63, P=0.002$, respectively). On both days, NCTC-109 with added chicken serum yielded a higher egg production than NCTC-109 alone (Fisher's LSD-test, $P<0.05$, for all post hoc comparisons between media with and without added chicken serum). There was, however, no significant difference in mean number of eggs per worm between the two groups cultivated in media supplied with $20 \%$ and $40 \%$ chicken serum, respectively, on either of the 2 days (Fisher's LSD-test, $P=0.123$, and $P=0.144$, after 24 and $48 \mathrm{~h}$ of cultivation, respectively).

Egg volume did not differ between treatments (Kruskal Wallis-test: $\chi_{2,297}^{2}=3.223, P=0.200$ ). There was, however, a weak but significant positive relationship between egg volume and number of eggs $\left(r_{\mathrm{s}}=0.147\right.$, $P=0.011, n=297$, worms pooled across treatments). In addition to normal looking eggs, eggs with abnormal structures were also present. This phenomenon is often observed in in vitro cultivation of trematodes (Fujino et al. 1977; Davies and Smyth 1979), although very little is known about the underlying mechanisms. One possible explanation is a premature tanning of the vitelline cells, leading to deformation of the eggshell (Davies and Smyth 1979). It is apparent that after $48 \mathrm{~h}$ of incubation,
Table 1 Mean number of eggs (range) in the uterus of in vitro adult Maritrema

novaezealandensis during a 5-day experiment. Each value represents the mean of a total of six replicates each consisting of five individuals $(n=30)$. In four replicates, the sample size was six instead of five. However, this did not affect the results and all replicates were thus included in the analysis

\begin{tabular}{|c|c|c|c|c|c|c|c|c|c|c|}
\hline \multirow[t]{2}{*}{ Medium } & \multicolumn{10}{|c|}{ Day of experiment } \\
\hline & 1 & & 2 & & 3 & & 4 & & 5 & \\
\hline & & $n$ & & $n$ & & $n$ & & $n$ & & $n$ \\
\hline NCTC-109 & $\begin{array}{l}18.0 \\
(6-95)\end{array}$ & 28 & $\begin{array}{l}29.5 \\
(0-79)\end{array}$ & 30 & $\begin{array}{l}25.1 \\
(0-102)\end{array}$ & 29 & $\begin{array}{l}15.5 \\
(0-36)\end{array}$ & 30 & $\begin{array}{l}11.0 \\
(0-32)\end{array}$ & 24 \\
\hline NCTC-109 & & & & & & & & & & \\
\hline$+20 \%$ chicken serum & $\begin{array}{l}36.2 \\
(0-104)\end{array}$ & 32 & $\begin{array}{l}49.0 \\
(1-120)\end{array}$ & 31 & $\begin{array}{l}43.1 \\
(0-165)\end{array}$ & 31 & $\begin{array}{l}12.3 \\
(0-127)\end{array}$ & 30 & $\begin{array}{l}7.5 \\
(0-59)\end{array}$ & 26 \\
\hline $\begin{array}{l}\text { NCTC- } 109 \\
+40 \% \text { chicken serum }\end{array}$ & $\begin{array}{l}46.8 \\
(6-95)\end{array}$ & 28 & $\begin{array}{l}64.4 \\
(12-195)\end{array}$ & 30 & $\begin{array}{l}25.6 \\
(0-142)\end{array}$ & 30 & $\begin{array}{l}13.0 \\
(0-48)\end{array}$ & 28 & $\begin{array}{l}5.8 \\
(0-64)\end{array}$ & 22 \\
\hline
\end{tabular}


Table 2 Mean \pm SE body length and width of in vitro adult $M$. novaezealandensis in three culture media. The data represent means from all 5 days of cultivation

\begin{tabular}{llll}
\hline Medium & $n$ & $\begin{array}{l}\text { Mean } \\
\text { length } \pm \text { SE }(\mu \mathrm{m})\end{array}$ & $\begin{array}{l}\text { Mean } \\
\text { width } \pm \text { SE }(\mu \mathrm{m})\end{array}$ \\
\hline $\begin{array}{l}\text { NCTC-109 } \\
\text { NCTC-109 }\end{array}$ & 118 & $412 \pm 5$ & $289 \pm 3$ \\
$+20 \%$ chicken serum & 134 & $431 \pm 4$ & $310 \pm 3$ \\
$\begin{array}{l}\text { NCTC-109 } \\
+40 \% \text { chicken serum }\end{array}$ & 110 & $438 \pm 5$ & $311 \pm 3$ \\
\hline
\end{tabular}

production of 'normal' eggs was inhibited by a factor not directly affecting survival of the worm. Culture medium was not replaced during the study, and a buildup of metabolic waste products or an exhaustion of essential nutrients may explain the observed pattern.

Mean worm length was significantly different between culture media (one-way ANOVA: $F_{2,361}=7.17$, $P=0.001$, Table 2 ). In vitro adults cultured in media supplied with chicken serum attained a larger size than worms cultured in NCTC-109 alone (Fisher's LSD-test, $P<0.05$, for all post-hoc comparisons between media with and without chicken serum). There was no difference in worm length between the two media containing chicken serum (Fisher's LSD test, $P=0.304$ ). A similar result was obtained for width of the in vitro adult worm. No growth was recorded after day 1 in any of the three culture media, indicating that the difference in size between the cultures was due to growth within the first $24 \mathrm{~h}$ of incubation. In fact, worms cultivated for 5 days started to contract and were significantly smaller than worms measured after 1 day of cultivation (unpaired $t$-test, $P<0.001$ for all treatments). As is generally the case for parasites, worm size $(L \times W)$ was positively related to the number of eggs in the uterus of in vitro adult $M$. novaezealandensis $(r=0.201, P<0.001, n=355$, worms pooled across treatments).

In conclusion, excystment of $M$. novaezealandensis metacercariae was relatively high in all media used, although the highest excystment success was obtained when metacercariae were cultured in NCTC-109 with or without chicken serum. Furthermore, maximum egg production in in vitro adult worms was obtained after $48 \mathrm{~h}$ when cultured in chicken serum enriched media. $M$. novaezealandensis thus follows the typical traits of Microphallidae by having a very short development time in the definitive host before the onset of egg production (see Galaktionov and Dobrovolskij 2003).
Acknowledgements We wish to thank K. Miller for photographic assistance. This study was funded by a grant from the Marsden Fund to R.P. The work in this study follows the guidelines of the University of Otago's Animal Ethics Committee.

\section{References}

Basch PF, DiConza JJ, Johnson BE (1973) Strigeid trematodes (Cotylurus lutzi) cultured in vitro: production of normal eggs with continuance of life cycle. J Parasitol 59:319-322

Berntzen AK, Macy RW (1969) In vitro cultivation of the digenetic trematode Sphaeridiotrema globules (Rudolphi) from the metacercarial stage to egg production. J Parasitol 55:136-139

Brown SP, Lorgeril J, Joly C, Thomas F (2003) field evidence for density-dependent effects in the trematode Microphallus papillorobustus in its manipulated host, Gammarus insensibilis. J Parasitol 89:668-672

Davies C, Smyth JD (1979) The development of the metacercariae of Microphallus similis in vitro and in the mouse. Int J Parasitol 9:261-267

Fredensborg BL, Latham ADM, Poulin R (2004a) New records of gastrointestinal helminths from the red-billed gull (Larus novaehollandiae scopulinus). NZ J Zool 31:75-80

Fredensborg BL, Mouritsen KN, Poulin R (2004b) Intensitydependent mortality of Paracalliope novizealandiae (Amphipoda: Crustacea) infected by a trematode: experimental infections and field observations. J Exp Mar Biol Ecol 311:253-265

Fujino T, Hamajima F, Ishii Y, Mori R (1977) Development of Microphalloides japonicus (Osborn, 1919) metacercariae in vitro (Trematoda: Microphallidae). J Helminthol 51:125-129

Galaktionov KV, Dobrovolskij AA (2003) The biology and evolution of trematodes. Kluwer, Dordrecht

Irwin SWB (1997) Excystation and cultivation of trematodes. In: Fried B, Graczyk TK (eds) Advances in trematode biology. CRC, Boca Raton, pp 57-86

Khan RN, Pacut JR, Pung OJ, Lawson V, Marshall M (2003) In vitro excystation of metacercariae of Microphallus turgidus under different physicochemical conditions. Parasitol Res 90:435-437

Lackie AM (1975) The activation of infective stages of endoparasites of vertebrates. Biol Rev 50:285-323

Martorelli SR, Fredensborg BL, Mouritsen KN, Poulin R (2004) Description and proposed life cycle of Maritrema novaezealandensis n. sp. (Microphallidae) parasitic in red-billed gulls, Larus novaehollandiae scopulinus, from Otago Harbor, South Island, New Zealand. J Parasitol 90:272-277

Thompson RM, Mouritsen KN, Poulin R (2005) Importance of parasites and their life cycle characteristics in determining the structure of a large marine food web. J Anim Ecol 74:77-85

Wang CL, Thomas F (2002) Negative influence of Gammarinema gammari (Nematoda) on the fecundity of Microphallus papillorobustus (Trematoda): field and experimental evidence. J Parasitol 88:425-427

Yasuraoka K, Kaiho M, Hata H, Endo T (1974) Growth in vitro of Parvatrema timondavidi Bartoli 1963 (Trematoda: Gymnophallidae) from the metacercarial stage to egg production. Parasitology 68:293-320 